\title{
SEVERABILITY OF COVENANTS IN PARTIAL RESTRAINT OF TRADE: A NEW RULE
}

Contracts In ReSTRAint of TRADE have long met with judicial re-
sistance from both American and English courts. That unlimited cove-
nants not to compete are void as against public policy is a proposition
unanimously supported by decisional as well as statutory law. ${ }^{1}$ Absent
a statute directing otherwise, however, limited covenants in partial re-
straint of trade will unquestionably be enforced if the restraint imposed
is reasonable ${ }^{2}$ as to the extent of space and length of time covered by the

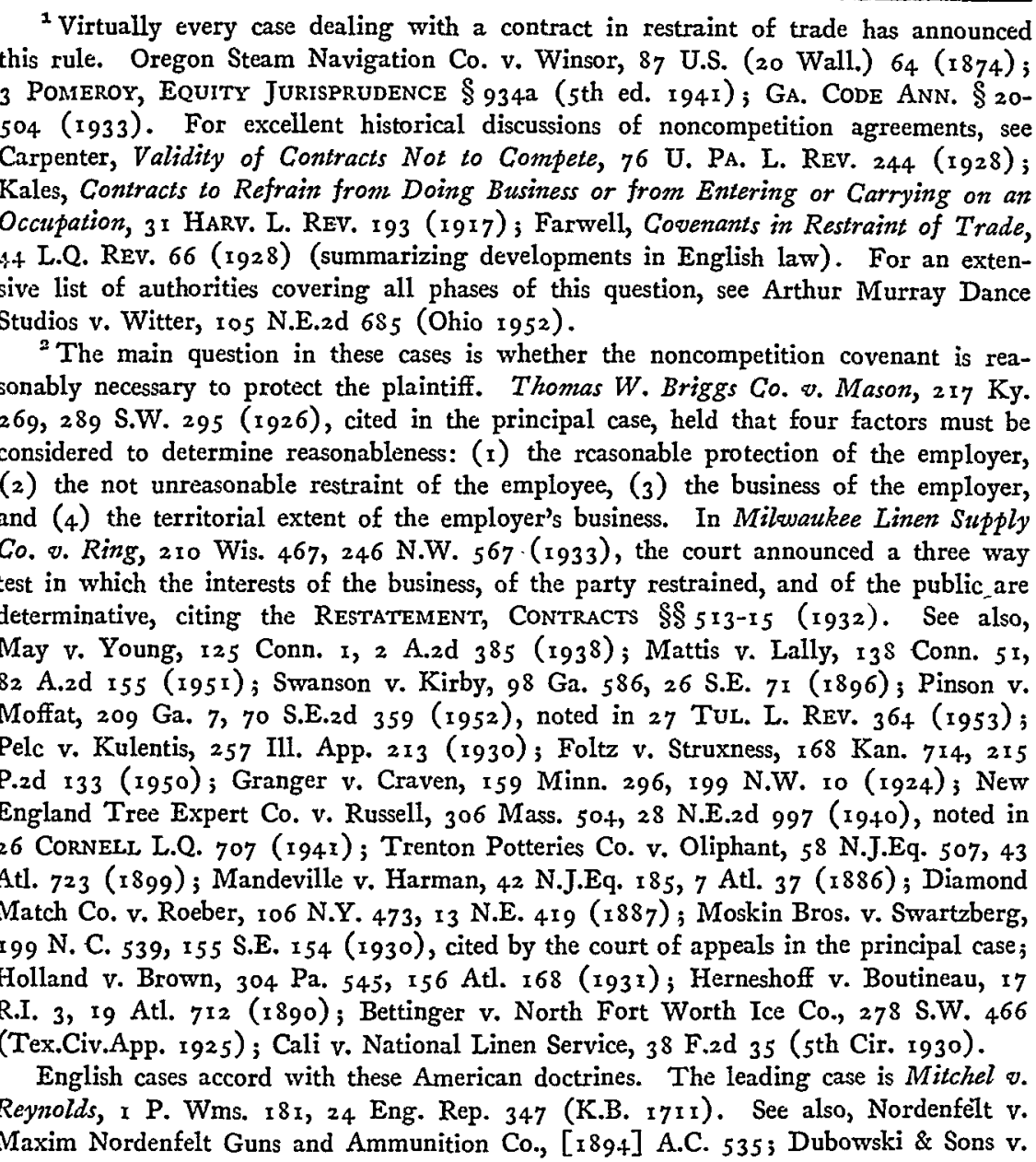


terms of the covenant. ${ }^{3}$ If a contract in partial restraint of trade fails to satisfy these requirements of reasonableness, the great preponderance of English and American courts will, to a greater or less degree, attempt to sever its terms ${ }^{4}$ and, thereafter, to enforce those portions which are reasonable. ${ }^{5}$

Goldstein [1896] I Q.B. 478; Mason v. Provident Clothing and Supply Co. [1913] A.C. 724 .

${ }^{3}$ Victor Chemical Works v. Iliff, 299 Ill. 532, 132 N.E. 806 (1921) (a contract unlimited as to time and space is void, absent proof that employee was aware of trade secrets); Wiley v. Baumgardner, 97 Ind. 66 (1884) (a contract for the sale of a business in which the noncompetition covenant contained a five-year time limit and was unlimited in territory, held void); Diamond Match Co., v. Roeber, 106 N.Y. 473, 13 N.E. $419(1887$ ) (a covenant not to compete in all of the United States and the territories except Nevada and Montana for ninety-nine years held reasonable). $\Lambda$ contract unlimited in space but limited as to time will be enforced if reasonable. Elbe File \& Binder Co. v. Fine, 137 Misc. 255, 242 N.Y.Supp. 632 (Sup.Ct. 1930). If there is no time limit expressed, the time is assumed to be for the lifetime of the person in whose favor it runs. Hauser v. Harding, 126 N.C. 295, 35 S.E. 586 (1900). But cf., Hall Mfg. Co. v. Western Steel \& Iron Works, 227 Fed. 588 (7th Cir. 1915), in which it was held that a restrictive covenant is not necessarily invalid if unlimited as to time and space, since public policy and honest business judgment must be balanced against each other.

The English cases similarly require reasonable limitations as to time and space. Ward v. Byrne, 5 M.\&W. 548, 151 Eng. Rep. 232 (Ex. 1839); Bromley v. Smith, [1909] 2 K.B. 235 ; Morris v. Saxelby, [1916] I A.C. 688 . In Stephens v. Kuhnelle (New South Wales 1926) 26 S.R. 327, noted in 26 Colum. L. Rev. 1041 (1926), a covenant not to solicit plaintiff's customers for one year and within a radius of five miles was held unreasonable because it included more than the customers actually served by defendant while in plaintiff's employ. Gilford Motor Co. v. Horne, [1933] Ch. 935. But cf., Rousillon v. Rousillon, L.R. 14 Ch. Div. 351 (1880) (limited territory is unnecessary if the contract is reasonable).

4 The prevailing rule declares that a contract is to be judged as an entirety only if its terms cannot be severed. Beit v. Beit, 135 Conn. I95, 63 A.2d I61 (1948); Consumers Oil Co. v. Nunnemaker, 142 Ind. 560, 4 1 N.E. x 048 (1895); Dole Refrigerating Co. v. Kold, 185 F.2d 809 (6th Cir. 1950); Interstate Finance Corp. v. Wood, 69 F. Supp. 278 (E.D. Ill. 1946); Wisconsin Ice \& Coal Co. v. Lueth, 213 Wis, 42, 250 N.W. 819 (1933). The doctrine of severability is discussed in 5 U. NEWARK L. REv. 124 (1940). See also, 5 WiLliston, Contracts $\$ 1659$ (rev. ed. 1937). The severability rule is supported by the REstatement, Contracts $\$ 518$ (1932).

${ }^{5}$ In John T. Stanley Co. ข. Lagomarsino, 53 F.2d 112 (S.D.N.Y. I931), cited by the court in the principal case as not militating against its renunciation of the severance doctrine, a covenant not to engage in a business involving the sale of fats, grease, bone, and soap was held divisible, and void only as to soap. In Edwards w. Mulllin, 220 Cal. 379, 30 P.2d 997 (1934), noted in 82 U. PA. L. REV. 872 (1934), a partnership agreement provided that on dissolution each partner would do business only in one-half of the state for a period of twenty-five years. The contract was severed, and the limitation held valid to the extent of Los Angeles County, although a state statue voided contracts in restraint of trade. See also, Hood v. Legg, 160 Ga. 620, 128 S.E. 891 
A recent holding by the United States Court of Appeals for the Fourth Circuit stands as a remarkable departure from this Anglo-American precedent of severance. Welcome Wagon $v$. Morris involved an employment contract in which defendant-employee covenanted not to engage in a business similar to that of plaintiff-employer for a period of five years after leaving the latter's employment. This noncompetition agreement covered the territory of (I) Gastonia, North Carolina, and/or (2) any other place in the United States or Canada in which plaintiffemployer is then engaged in rendering his services, and/or (3) any other place in the United States or Canada in which plaintiff-employer has been or has signified his intention to be engaged in rendering his services. $^{7}$

On plaintiff's appeal from an adverse judgment in the district court, ${ }^{8}$ the restrictive covenant was held unreasonable as to length of time and extent of space, and, therefore, void and unenforceable. In answer to

(1925) (a covenant restraining defendant from selling brick or other clay products was severed and held enforceable only as to the sale of brick); General Bronze Corp. v. Schmeling, 208 Wis. 42, 243 N.W. 469 (I932), noted in I7 MINN. L. REv. 86 (1932) (a covenant encompassing all of the United States, Canada and Mexico, except Nevada, held valid only as to the United States); Pelc v. Kulentis, 257 Ill. App. 213 (1930); Bennett v. Carmichael Produce Co., 64 Ind.App. 341, 115 N.E. 793 (1917); Davey Tree Expert Co. v. Ackelbein, 233 Ky. I 15,25 S.W.2d 62 (1930); Sherman v. Pfefferkorn, 24I Mass. 468, I35 N.E. 568 (I922); Fort Smith Light \& Traction Co. v. Kelley, 94 Ark. 46I, I27 S.W. 975 (1910); Peltz v. Eichele, 62 Mo. I71 (1876); Central N.Y. Tel. \& Tel. Co. v. Averill, 199 N.Y. I28, 92 N.E. 206 (1910); Smith's Appeal, II3 Pa. 579, 6 Atl. 25I (1886); John Roane, Inc. v. Tweed, 89 A.2d 548 (Del. 1952).

The English cases, similarly, follow the severability rule. The leading English case is Price v. Green, 16 M.\&W. 346,153 Eng. Rep. 1222 (Ex. I 847) in which a covenant not to compete in London and Westminster or six hundred miles therefrom was enforced only as to London and Westminster. See also, Rogers v. Maddocks, [1892] 3 Ch. 346, (a covenant not to sell aerated waters or malt liquors within one hundred miles of Cardiff, held enforceable as to malt liquors only); Dubowski \& Sons v. Goldstein, [1896] I Q.B. 478 , (a covenant never to interfere with P's customers held severable and enforceable only as to customers $P$ had while $D$ was in his employ); Pickering $v$. Ilfracombe Ry. Co., L.R. 3 C.P. 235, 250 (1868), discussed in 13 N.Z.L.J. 205, 22I, 24I (1937).

${ }_{224}$ F.2d 693 (4th Cir. 1955). Judge Dobie delivered the opinion for a unanimous court.

${ }^{7}$ This is a paraphrase of the actual covenants, but each was, in fact, enumerated in the manner set forth.

${ }_{129}$ F.Supp. I (W.D.N.C. 1955). The district court held that defendant's newly acquired employment was not similar to the plaintiff's busimess. The court of appeals held that this finding was error, but affirmed on the ground that the contract was void for unreasonableness. 
plaintiff's contention that the specifically enumerated provisions were separable and should be enforced as to the first provision only, the court of appeals replied that "the restrictive covenant must be judged as a whole and must stand or fall when so judged."

In this case, the Fourth Circuit was interpreting and applying the law of North Carolina; and, in announcing its decision, the court declared that it could find nothing in the law of that state which militated against the position it had taken. Oddly enough, however, in one of the cases cited in the course of the opinion, the North Carolina Supreme Court severed the unreasonable covenants of a contract in partial restraint of trade, even though such severance necessitated an actual rewriting of the contract terms. ${ }^{10}$ Nevertheless, the fact that the Welcome Wagon decision has been handed down by a United States court of appeals makes it particularly notable-representing, perhaps, a calculated innovation by a small, yet relatively significant, minority. If, in fact, the decision in the principal case marks the incipience of a new minority rule, then the various Anglo-American jurisdictions are now divided into four distinct groups on the question of severability.

First, the approach adopted by a majority of courts is to read out of the contract those unreasonable clauses which are, by their very terms, separable." This judicial technique is frequently designated the "blue

${ }^{\circ} 224$ F.2d at 70 I.

${ }^{10}$ In Hauser v. Harding, 126 N.C. 295,35 S.E. 586 (1900), defendant covenanted not to practice medicine in "the territory surrounding Yadkinville." The court held that the terms of the covenant were too indefinite, and the restraint would be rewritten to include only the corporate limits of Yadkinville. The North Carolina rule, therefore, would seem to be that a contract in partial restraint of trade can be severed and partially enforced.

In Noe v. McDevitt, 228 N.C. 242,45 S.E.2d 12 I (1947), plaintiff, owner of a barber supply company, employed defendant as a salesman. Defendant covenanted that, on leaving plaintiff's employ, he would not engage in a similar business in North or South Carolina for five years. In a subsequent suit against the defendant, the North Carolina Supreme Court held the covenant void as unreasonably extensive. Certain language in the opinion resembles that of Judge Dobie in the principal case: "The Court cannot by splitting up the territory make a new contract for the parties-it must stand or fall integrally." 228 N.C. at 245,45 S.E.2d at 123 . It is strange that the court of appeals does not refer to that language in rejecting the severance rule, but rather cites Hauser v. Harding, supra, as a case that does not "militate against" the position taken. 224 F.2d at 70r. The court did, however, cite Noe v. McDevitt for two propositions: ( $\mathrm{x}$ ) the territory in the covenant must be reasonably necessary to protect the employer's business, and (2) an unreasonable restraint must not be imposed on the employee. 224 F.2d at 699.

${ }^{11}$ See cases cited note 5 supra. 
pencil rule," since the test announced by the courts in determining separability is whether a blue pencil can be drawn through the unreasonable covenants, leaving the valid ones to stand independently. ${ }^{12}$

An increasing number of other states have gone to further lengths, and, rather than invalidate an unreasonable and indivisible contract, have assumed the burden of interpolating divisibility into the text of the covenants. ${ }^{13}$ In these jurisdictions, contracts in partial restraint of trade can be drafted in the most comprehensive terms, with the confidence that the court will rewrite the covenants to give the plaintiff-employer the broadest protection allowed by law. ${ }^{\mathbf{1 4}}$

${ }^{12}$ The American cases cited in note 5 supra, illustrate various applications of the "blue pencil rule." There is still some doubt as to the applicability of this rule in England. In Goldsoll v. Goldman, [1914] $2 \mathrm{Ch} .603$, a contract for the sale of a business included a covenant that the seller not compete for two years in the United Kingdom, the Isle of Man, France, the United States, Russia, Spain, Vienna or within twenty-five miles of Potsdamerstrasse. This single covenant was severed and held valid to the extent of the United Kingdom. Six years later in Attwood v. Lamont, [1920] 2 K.B. 146, an employment contract containing a covenant not to engage in the business of a tailor, designer, etc., was severed and held valid as to the occupation of tailor only. In [1920] 3 K.B. $57 \mathrm{I}$, this decision was reversed, the court rejecting the "blue pencil rule." They held that covenants are severable only when distinct; parts of a single covenant will not be severed.

Ronbar Enterprises, Ltd. v. Green, [1954] 2 All E.R. 266 (C.A.) is the most recent English case on this question. The Goldsoll and Attwood decisions supra, were distinguished by the peculiar facts of each; and, having made this distinction, the court reverted to the "blue pencil rule" of the Goldsoll case in upholding a noncompetition covenant in a contract for the sale of a business. But even under the more conservative Attwood rule requiring a number of distinct covenants, the Welcome Wagon covenants could be severed.

${ }^{13}$ The New Jersey or Massachusetts rule has emerged from several decisions holding that an inseparable covenant will be construed as divisible, if such is the presumed intention of the parties. In Fleckenstein Bros. ข. Fleckenstein, 76 N.J.L. 61 3,71 Atl. 265 (1908), the parties contracted not to compete in the bologna business for twenty years within five hundred miles of Jersey City, New Jersey. The court held the contract divisible by construing it to read "either in Jersey City or within five hundred miles from that city." In Trenton Potteries Co. ข. Oliphant, 58 N.J.Eq. 507, 43 Atl. 723 (1899), defendant covenanted against competing "within any state in the United States." A divisible contract was created by construing the terms to read "within Alabama, within Arizona . . . etc."

${ }^{14}$ In the more liberal jurisdictions it is not necessary to hold the contract severable, since the courts will simply create their own rcasonable contracts. See General Paint Corp. v. Seymour, I24 Cal. App. 6II, I2 P.2d 990 (1932) (a covenant not to compete for five years in the State of California held valid as to Los Angeles); Foltz v. Struxness, r68 Kan. 71, 215 P.2d I33 (1950) (a covenant "within the city of Hutchinson or within one hundred miles" was held valid as to the city and a five mile radius therefrom); Ceresia v. Mitchell, 242 S.W.2d 359 (Ky. I951), noted in 32 B.U.L. REv. 224 ( 1952 ) (a covenant not to engage in any business whatsoever in the same county 
In contrast to this trend in the courts, a few states, in recent years, have passed statutes declaring void and unenforceable all contracts in partial restraint of trade, with some narrowly defined exceptions. ${ }^{15}$

And, finally, under the rule of the Welcome Wagon case, courts would enforce only those noncompetition agreements which are reason-

for an unlimited time, held valid as to a competing business for a term of ten yearsthe term of plaintiff's lease); Edgecomb v. Edmonston, 257 Mass. 12, 153 N.E. 99 (1926) (covenant not to engage in a similar business in Massachusetts for a period of five years held a valid restraint from competing in Boston and from soliciting customers in Massachusetts); Herrington v. Hackler, 181 Okla. 396, 74 P.2d 388 (1937) (one hundred mile radius cut down to confines of one county); Hartman v. Everett, 158 Okla. 29, I2 P.2d 543 (1932) (area including all of the United States reduced to one county); Eldridge v. Johnston, I95 Ore. 379, 245 P.2d 239 (I952), noted in 32 OrE. L. REv. 260 (1953) (a covenant covering all of Oregon and Washington, held valid as to four Oregon countics) ; Hill v. Central West Public Service Co., 37 F.2d 451 (5th Cir. 1930) (a covenant encompassing all of Texas, held valid as to city of Dallas); John T. Stanley Co. v. Lagomarsino, 53 F.2d 112 (S.D.N.Y. 1931) (New York and New Jersey reduced to the area where plaintiff does business); Whiting Milk Companies v. O'Connell, 277 Mass. 570, I79 N.E. 169 (1931), noted in 45 HARv. L. REv. 75I (1932), I2 B.U.L. REv. 273 (1932); Metropolitan Ice Co. v. Ducas, 291 Mass. 403, 196 N.E. 856 (1935); Burroughs Adding Machine Co. v. Chollar, 79 S.W.2d 344 (Tex.Civ.App. 1935); Pancake Realty Co. v. Harber, 137 W.Va. 605, 73 S.E.2d 438 (1952); Note, 1 Buffalo L. Rev. 181 (1951). Professor Corbin urges the rejection of the "blue pencil" rule in favor of the New Jersey rule. 6 CoRBIN, CoNTRACTS $\$$ I 390 (I95I).

${ }^{15}$ CAL. Bus. \& Prof. Code $\S$ I 6600 (Deering, 1941) provides that all contracts in restraint of trade are void unless they fall within exceptions such as partnership agreements or the sale of business goodwill. Under this statute, the courts have severed covenants, upholding the ones that fall within an exception. Neverthless, an employee cannot be restrained from competing with his employer. Morris v. Harris, $127 \mathrm{Cal}$. App.2d 476, 274 P.2d 22 (1954).

LA. REv. STAT. \$23:921 (1950): "No employer shall require or direct any employee to enter into any contract whereby the employee agrees not to engage in any competing business ... u upon the termination of his contract of employment with such employer, and all such contracts, or provisions thereof . . . shall be null and unenforceable in any court."

Mich. CoMp. LaWs $\$ \S 445.76 \mathrm{r}, 445.766$ (1948), declares that all contracts not to engage in any "avocation, ... . profession, ... . whether reasonable or unreasonable, partial or general, limited or unlimited, are hereby declared to be against public policy and illegal and void." There are certain narrow exceptions: covenants protecting the vendee in the sale of a business, and covenants in employment contracts prohibiting the covenantor from soliciting the covenantee's customers for ninety days after the termination of the employment contract.

The Oklahoma statute, OKLA. Stats. ANN. tit. 15, §§ 217-219 (1937), is modeled after the California statute, supra. In E. S. Miller Laboratories, Inc. \&. Griffin, 200 Okla. 398, 194 P.2d 877 (1948), a noncompetition covenant in an employment contract was held not to fall within a statutory exception, the court citing the California statute, supra, and Morris v. Harris, supra. 
able as an entirety. This new position was certainly not taken by the Fourth Circuit in response to general adverse criticism of the "blue pencil rule." Quite the contrary, most arguments addressed to the problem seek to justify the rule of severability, in either its conservative or more liberal form. The requirement of severance imposes no intolerable burden on the courts; and, as a matter of simple contract law, such a rule probably better effectuates the "intent of the parties." Therefore, it is argued, since reasonable contracts in restraint of trade are enforceable, there is nothing which should prohibit the courts from eliminating the unreasonable terms and giving effect to the balance. ${ }^{16}$

This argument, however, overlooks certain very undesirable collateral effects of severance. Once having agreed not to compete for a prescribed period, a covenantor who has terminated his employment will, more likely than not, strictly adhere to the broadest terms of his contract. This adherence will be prompted, in part, by the financial inability of the covenantor to litigate his rights, ${ }^{17}$ and, in part, by a commendable respect for what appears to be a legal obligation. ${ }^{18}$ Consequently, the practical

${ }^{10}[\mathrm{~T}]$ he judicially made (or modified) contract approximates the one made by the parties and is certainly more satisfactory to one whose protection is in question than entire loss of protection would be, and the other party ought not to object to a lawful restraint which is less than he agreed upon voluntarily and for which he has been paid." Breckenridge, Restraint of Trade in North Carolina, 7 N.C.L. REv. 249, 258 (1929). Similar arguments abound in the cases and articles which favor the doctrine of severance and the New Jersey rule.

${ }^{17}$ That the threat of litigation acts as a deterrent to the breach of an unreasonable covenant is an argument formulated in a dictum by Lord Moulton in Mason $v$. Provident Clothing \& Supply Co., [1913] A.C. 724, 745. "It would in my opinion be pessimi exempli if, when an employer had exacted a covenant deliberately framed in unreasonably wide terms, the courts were to come to his assistance and . . . carve out of this void covenant the maximum of what he might validly have required. It must be remembered that the real sanction at the back of these covenants is the terror and expense of litigation, in which the servant is usually at a great disadvantage, in view of the longer purse of his master. . . [T] [Te hardships imposed by the exaction of unreasonable covenants by employers would be greatly increased if they could continue the practice with the expectation that, having exposed the servant to the anxiety and expense of litigation, the Court would in the end enable them to obtain everything which they could have obtained by acting reasonably."

${ }^{18}$ Note, 45 Harv. L. REV. 75 I (1932) points out that the employee's belief that the contract is valid can lead to undesirable results. This criticism was particularly aimed at the liberal holding in Whiting Milk Companies $0 . O^{\prime}$ Connell, 277 Mass. 570, I79 N.E. 169 (I93I). The Massachusetts rule, as first promulgated in Edgecomb v. Edmonston, 257 Mass. I2, 153 N.E. 99 (1926), is severely criticized in Note, 40 HARV. L. REv. 326 (1926), where the writer calls for an abolition of the doctrine, because it effectuates a contract secured by an employer who holds the balance of bargaining power in negotiations with an individual employee. 
effect of a severability rule is to allow an employer to restrain trade under the pretext of an enforceable contract and, at the same time, to run no greater risk than that of having his contract pared down to what public policy will actually countenance.

The courts have determined that an employer who has trained an employee in a special capacity should be allowed to enter into agreements reasonably necessary to protect his business interests. To this extent the law accords the employer a special privilege-a dispensation from the general rule that no one will be allowed to deprive the business community of an individual's services. In return, therefore, the employer should bear the correlative burden of drafting his noncompetition contracts narrowly, so as not unnecessarily to deprive society of the economic services of an employee.

In sum, it appears that the courts in those jurisdictions which have adopted the doctrine of severability are encouraging the employer to take an unfair advantage of an unusual privilege. The rule of the $W e l$ come Wagon case would act as a powerful deterrent to such abuses. While it is perhaps regrettable that the court did not expound this novel doctrine with greater particularity in its opinion, the rule, in light of the foregoing considerations, appears to be quite justifiable.

WinsLow DRUMMOND 